\title{
REACHING AN ENTREPRENEURIAL MANAGEMENT SYSTEM OF AMOEBAS. A QUALITATIVE INSIGHT INTO THE EUROPEAN EXPERIENCES
}

\author{
WIEStAW URBAN, JOANNA CZERSKA
}

\begin{abstract}
A B S TR A C T
The aim of the study is an assessment of the Amoeba Management System (AMS) introduction advancements in some European companies. The study takes the practically focused research approach. The approaches, achievements and phases whilst introducing the AMS principles by companies are observed and critically assessed. First insight into the challenges of AMS introduction is taken basing on critical study of the literature output. The scientific studies and managerial publications are taken into consideration. The empirical part of the study is based on the qualitative approach. A multiple case study methodology is employed. The research objects are three companies, one of them operates in Sweden, the next two in Poland. Each of them have different experiences in AMS implementation, they also manifest different management styles and habits. The study demonstrates that AMS is a very prospective management methodology which can support companies in employees commitment during their journey towards operational excellence. The analysis results show different motivations for AMS introduction as well as different development paths, these are harmonized with different management styles in companies and culture occurring in countries. The study is particularly valuable because this is one of the first empirical investigations of AMS implementation in European companies. In the field of theory the study proposes the four level scale for amoebas system maturity. This scale allows to classify companies following AMS principles and, at the same time, this scale is also the kind of path of AMS implementation. The study points out basic tools for companies which support AMS implementation. These tools are already known in management literature, but experience of investigated companies shows that they are fundamental for successful AMS implementation.
\end{abstract}

KEY WORDS

Amoeba Management, Kyocera, self-governed units, autonomous teams, employees engagement, employees productivity

DOI: 10.1515/emj-2016-0001
Corresponding authors:

Wiesław Urban Bialystok University of Technology Faculty of Management

e-mail:w.urban@pb.edu.pl

Joanna Czerska LeanQ Team sp. z o.o.

e-mail: jczerska@lean.info.pl

\section{INTRODUCTION}

Market challenges and rising customer requirements create the need of faster and deeper improvements of business processes in companies. According to the survey conducted by Aberdeen Group, the remapping and reengineering of business process as well as increased attention on serving customers are the most important present business challenges (Castellina, 2015a, p. 3; Castellina, 2015b, p. 3). At the same time this research shows that nowadays competitiveness, more than ever, take advantage of real and deep employees entitlement and engagement. According to the Report of Trends in Global Employee Engagement (Hewitt, 2015, p. 3), an engaged workforce have the primary importance for companies financial performance. Companies more often devote attention to measuring 
and fostering employees loyalty, seeing it as the key for having deeply involved people in an organization. For example, a global company Tesco measures employees involvement around the world and has the strategy for developing this issue taking into consideration local culture contexts (Hay Group, 2014, p. 20).

Top managers are aware of all these market pressure and fundamental role of workforce engagement, therefore they are looking for appropriate concepts and tools. One of very interesting proposal is the concept of Amoeba Management System (AMS) by Inamori Kazuo. His idea is to lead a business basing on autonomous teams within all the company. Despite this idea has not been widely discussed in the literature, AMS has been spreading all over the world recently, including several introductions in the Europe. Multinational companies have mostly transferred the amoeba concept along countries and industries. Whilst we have basic knowledge of how the AMS operates in Japanese Kyocera, where it was originally developed, and what effects it brought, we do not have reported experiences of how amoeba approach works in different countries, particularly in European ones. Considering there are cultural differences and different approaches in management, substantial variances in AMS might occur.

The study aims at multi-criteria analysis of amoebas system which has being introduced in companies apart the Kyocera Group, particularly in Europe. The study aims to observe and to assess critically the approaches, achievements and phases of introduction of the AMS principles by European companies. The qualitative research approach is employed to this study. This is constrained by limited number of potential research objects, the strive for a deeper understanding of a research problem, as well as limited amount of literature knowledge on AMS introduction. Practical managerial needs form a real focal point of the empirical analysis and theorizing attempts.

\section{FundAMENTALS OF AMOEBA MANAGEMENT}

The concept of AMS has origins in Kyocera, Japanese company. The system had been developed by Kyocera's cofounder Kazuo Inamori who had been its CEO for a long time. When Inamori was starting with his startup he experienced many adversities; they influenced very much the design of his unique management system and a business philosophy laying behind it. Managers and researchers desire and appreciate effective organizational system, i.e. very productive and leading to continuous growth. The system of amoebas introduced by Kyocera gave this company more than 50 years of consecutive profitability (Adler \& Hiromoto, 2012, p. 83). Kyocera reached the yearly revenue 12 billion USD in the fiscal year 2013/2014, the capital group included 230 companies (Sawabe, 2015, p. 11). Takeda and Boyns (2014), who analysed Kyocera's growth path, present many evidences demonstrating market expansiveness, dynamic productivity increase as well as competitiveness improvement. The AMS is equally effective in the manufacturing industry and in the service. The author of amoeba methodology became the CEO of Japan Airline in 2010, at this time the company was threaten with bankruptcy. Introduction of AMS methodology resulted in a profit immediately, within two years (Takeda \& Boyns, 2014, p. 318). This is considered that these outstanding results are achieved, first of all, thanks to entrepreneurial teams comprised of highly engaged workforce - the foundations of AMS.

\subsection{Autonomous teams}

The system developed at Kyocera is based on the independent units of workers; these units operate almost like independent business inside a company. An organizational unit is called "amoeba" because it is very small and very flexible, and at the same time very simple, so this is like biologic amoeba, which is a very simple organism. A company organised according to AMS, even a huge one like Kyocera, is composed of a number of small units focused on the value and their individual profits. Each amoeba works according to a fundamental bussines principle: maximize revenues, minimize expenses (Inamori, 2013, p. 7).

The basic organizational unit, amoeba, is to some extend similar to an independent business. The autonomy of amoebas consist of endowed authority to set and execute their own plans, as well as operating on their own settlement. The size of amoebas may differ, according to Sawabe, Kazusa and Ushio (2008, p. 19) in Kyocera typical size of amoeba is $10-15$ members; others inform that amoeba is composed of 3-50 employees (Hamada \& Monden, 1989, p. 199). 
All functions of a company are organized in amoebas, there are amoebas serving in administration, production, sales and other functions. In the main operations specific amoebas handle successive stages of processes.

The amoeba is managed by one leader, (s)he is responsible for achieving planned targets of an amoeba. Generally the amoeba system is considered as a system governed by all (Adler \& Hiromoto, 2012, p. 85; http://global.kyocera.com, 21.01.2016). But the amoebas' leaders, without doubts, play the paramount role. Some authors even call amoeba leaders as "feudal lords" supervising his or her unit in his or her own way (Sawabe \& Ushio, 2009). According to the architect of the AMS, the amoeba leader acts like a head of small or medium-sized enterprise, (s)he has the same sense of responsibility and sense of mission like a SME's head (Inamori, 2013, p. 51). But first of all the amoeba manager responsibility is concern for the economic efficiency of his (her) unit. Another crucial issue is the ability of leaders to promote their people empowerment (Adler \& Hiromoto, 2012, p. 86). Thus, the leaders' managerial abilities and skills are in serious focus of interests in AMS.

The coordination between amoebas are mostly based upon leaders and amoeba's employees. There are meetings at three levels, manager meetings divisional managers and sectional managers, sectional meetings - sectional managers meet with amoeba leaders, amoeba meetings - within amoeba with its leader (Sawabe, 2015, p. 25). All these meetings are the everyday routine. Adler and Hiromoto (2012, p. 84) inform that machine operators and other amoeba members attended of 30 minutes of meetings a day, leaders and senior managers have scheduled meetings of 45 to 60 minutes. Sawabe $(2015$, p. 25) observations show that each meeting at Kyocera lasts around 5-10 minutes.

Amoebas, the independent and self-governed units (autonomous teams), need clear rules to work effectively for a company business success. Very strong organizational philosophy and strict economic settlements serve for amoebas as guideposts in every day operations, and help in management decisions.

\subsection{AMS PHILOSOPHY}

Amoebas system founder sees numerous drawbacks of so far-reaching amoebas independence. The solution is firmly rooted philosophy of actions in the whole company (Inamori, 2013). This AMS philosophy can be summarised as „do what is right as human being" (Inamori, 2013, p. 31). This simple principle makes the cooperation between independent (autonomous) amoebas smooth and flexible, it allows to avoid egoisms and particularisms among amoebas.

Practically the philosophy at Kyocera is more complex and it is consisted of: corporate motto, management rationale, principles and philosophy keywords (Takeda \& Boyns, 2014, p. 328). The motto and the rationale jointly are the brother frame and explanation of the central point of the philosophy respect for divine and people. The twelve management principles allows the dipper understanding of the Kyocera philosophy. These principles are a kind of ethically focussed general tips for behaviours and personal attitudes, they are very similar to believes in their nature. The keywords broaden the meaning and understanding of the philosophy.

The twelve principles refer to two fundamental issues. First one are individual personal virtues, another says of organizational/business philosophy. For example, the third management principle mentions „Keep a passionate desire in your heart” (http://global.kyocera.com, 21.01.2016). Additional explanations inform this is not about accidental attitudes but about the permanent and lasting passion which is desired, rooted in the deep levels of human mind. Another principle referring to human virtues says „Strive harder than anyone else” (http://global. kyocera.com, 21.01.2016), this is fourth principle. It gives the real challenge to everyone in an organization. At the same time it is very idealistic.

The management principles referring to business/ organization are concentrated more on teams' practice, although still to some extent idealistic. The fifth principle is "Maximize revenues and minimize expenses" (http://global.kyocera.com, 21.01.2016). This is a fundamental rule of economic rationality. But in this case the interpretation is that amoebas must measure both variables, and not to chase the profit, it should always be an effect of undertaken efforts. Another organizational tip presents the principle number ten: "Always be creative in your work" (http://global.kyocera.com, 21.01.2016). This is an encouragement for innovativeness on the work stations and continuous improvement. Each day at work should carry some kind of positive changes.

The philosophy at Kyocera is far disaggregated and conspicuous, it is inbuilt in organizations in many ways. First of all, it is described in printed hard version as The „Kyocera Philosophy Pocketbook” 
(Sawabe et al., 2008, p. 88). This book is given to each employee on the first day (s)he come to the company. Additionally, during the morning meetings employees read pieces of this book (Sawabe, 2015, p. 26). The company also prizes all the values comprised in the philosophy. As the founder mentions, Kyocera, as no other company in the world, places so much importance on basic values of justice, fairness courage and perseverance (Inamori, 2013, p. 33). For years this allowed to develop the strong corporate culture. Adler and Hiromoto (2012, p. 85) underline that this ethics and human challenges focused corporate culture serves as the primary mechanism of making sure that the interests of the organization come first.

\subsection{The ACCOUNTING System}

The third pillar of AMS, beside the autonomous teams and meaningful organizational philosophy, is a very distinctive accounting system in a company. In Inamori opinion mentioned in his book (Inamori 2014 , p. 24), the traditional accounting system operates on global figures and it reports the historical data, which is totally useless for AMS approach. The idea of AMS is to base on the real economic conditions in each elementary unit forming this system, so that each unit must have real and timely economic calculation. First of all AMS implements internal transfer prices between amoebas. These amoebas transfer prices are determined through a process of bargaining and negotiations, so that reflect market prices (Takeda \& Boyns, 2014, p. 340). The selling prices determine the amoebas profits, but whilst setting the selling prices amoeba cannot consider only its own profit but also a profitability of whole company (Inamori, 2013, p. 51). Amoebas compete, subcontract, and cooperate among themselves on the basis of the intracompany market, which is an equivalent of a real market (Blahová, 2013, p. 31).

Having internal transfer prices between amoebas this is possible to calculate precisely value added in each amoeba. Value added, called as amoeba profit, is the balance remaining after subtracting the total expenses, other than labour costs, form net value of production sold to other amoebas (Inamori, 2013, p. 63). The total expenses include absolutely all costs tied to facilities engaged and operations done by amoeba. The internal interests are also calculated with reference to capital as well as inventories. The calculation aim is to determine the "workers" profit' and "hourly workers" profit', these two constitute the main indicators for amoeba management. What is important, labour salaries and accompanying expenditure do not bear the workers' profit. This is the key element of Inamori's philosophy, the higher labour costs are not seen, per se, as something bad what has to be reduced (Takeda \& Boyns, 2014, p. 339).

The accounting system at Kyocera is referred to as a diagnostic control system (Sawabe, 2015, p. 24). The amoeba results are planned monthly and yearly in financial figures. Each month the reporting meetings are held. During meetings the financial performance of the prior month is presented and discussed in relations to monthly targets and annual targets. Adler and Hiromoto (2012, p. 87) underline that at Kyocera they devote much attention to ensure that this accounting information accurately reflects internal and external transactions of each amoeba on the daily basis. Alike Inamori (2013, p. 53), who mentions the fundamental role of Business Systems Administration Department at Kyocera. This department handles the quantitative information of the entire company. It provides the information necessary to steer all operations. The AMS use this information like an aircraft navigator reads and interprets instrument panels and gauges in a cockpit (Inamori, 2013, p. 53) in real time.

\section{AMS IMPLEMENTATION NODAL POINTS IN EUROPEAN PERSPECTIVE}

Analysis of Inamori (2014) AMS concept shows set of challenges which can be seen in different way from three key positions in organization: worker point of view, amoeba leader point of view and managers point of view. These are presented in Tab. 1.

Taking into consideration 6 challenges mentioned in Tab. 1 and being guided by Smythe (2009), Burns (2005), Levine (2006, pp. 375-380) and by guidelines coming from researches Aon Hewitt (2015) and Hay Group (2014), we can assume that most of them is connected with managers attitude and company management culture based on mission and values of organization. This lead to conclusion that fundamentals of AMS lay in behavioural area of all workers from all levels of organization, what creates the need to prepare the staff to co-create and work in new working environment. 
Tab. 1. Challenges of AMS from different points of view

\begin{tabular}{|c|c|c|c|}
\hline Challenge & WORKERS POINT OF VIEW & $\begin{array}{l}\text { TEAM LEADERS } \\
\text { (AMOEBA LEADERS) } \\
\text { POINT OF VIEW }\end{array}$ & MANAGERS POINT OF VIEW \\
\hline $\begin{array}{l}\text { Concentrate on work- } \\
\text { er needs and on what } \\
\text { motivate him to take } \\
\text { responsibility }\end{array}$ & $\begin{array}{l}\text { Worker wants to protect his } \\
\text { home budged now and in the } \\
\text { future } \\
\text { Need of daily sense of mean- } \\
\text { ing and satisfaction of what } \\
\text { am I doing }\end{array}$ & $\begin{array}{l}\text { The main target is to } \\
\text { work out profits to } \\
\text { ensure salary for } \\
\text { my workers }\end{array}$ & $\begin{array}{l}\text { To motivate and lead the } \\
\text { amoeba team leaders in goals } \\
\text { achievement } \\
\text { Win the challenge to break } \\
\text { through the conflict between } \\
\text { workers and employer }\end{array}$ \\
\hline $\begin{array}{l}\text { Create mission and } \\
\text { give the know-how } \\
\text { to fulfil the mission }\end{array}$ & $\begin{array}{l}\text { Worker to be an entrepreneur } \\
\text { and care about company re- } \\
\text { sults should know the financial } \\
\text { result of his amoeba team. } \\
\text { Each worker has real influence } \\
\text { on a work organization }\end{array}$ & $\begin{array}{l}\text { To be entrepreneur cre- } \\
\text { ating long and medium } \\
\text { term goals business } \\
\text { plans, having the knowl- } \\
\text { edge about value stream } \\
\text { connected with finance } \\
\text { management. Processes } \\
\text { and tasks organization is } \\
\text { the team responsibility } \\
\text { and authority }\end{array}$ & $\begin{array}{l}\text { To be concentrated on human } \\
\text { resources management and } \\
\text { financial results in the same } \\
\text { time. Be a guide (define and } \\
\text { protect company values and } \\
\text { key rules) for subordinated } \\
\text { amoebas' team leaders }\end{array}$ \\
\hline $\begin{array}{l}\text { No limits rule must be } \\
\text { the attitude }\end{array}$ & \multicolumn{3}{|l|}{ There is no limits in cost reduction } \\
\hline $\begin{array}{l}\text { Salary should not be } \\
\text { a driver of results } \\
\text { achievement }\end{array}$ & \multirow{2}{*}{$\begin{array}{l}\text { Workers salary should not be } \\
\text { depended on short term orga- } \\
\text { nization profitability, but on his } \\
\text { competencies. Lower results } \\
\text { can't have the influence on } \\
\text { salary level }\end{array}$} & $\begin{array}{l}\text { Promote and develop } \\
\text { competencies of each } \\
\text { worker according to com- } \\
\text { pany needs }\end{array}$ & $\begin{array}{l}\text { Promote and develop compe- } \\
\text { tencies of each amoeba leader }\end{array}$ \\
\hline $\begin{array}{l}\text { Profit for company is } \\
\text { the main target. Profit } \\
\text { of amoeba is what is } \\
\text { under daily control of } \\
\text { leaders and workers }\end{array}$ & & $\begin{array}{l}\text { Setting the sales price } \\
\text { between amoebas is the } \\
\text { mature discussion and } \\
\text { profit share between } \\
\text { amoebas }\end{array}$ & $\begin{array}{l}\text { Ensure wide access to infor- } \\
\text { mation about company situ- } \\
\text { ation. Take on the challenge } \\
\text { only when its teams are pre- } \\
\text { pared for it }\end{array}$ \\
\hline $\begin{array}{l}\text { Flexible structure of } \\
\text { autonomous teams }\end{array}$ & \multicolumn{2}{|c|}{$\begin{array}{l}\text { Organization of the autonomous team can be changed any } \\
\text { time }\end{array}$} & $\begin{array}{l}\text { Flat organization structure } \\
\text { adopting to current company } \\
\text { needs }\end{array}$ \\
\hline
\end{tabular}

Source: own compilation based on (Inamori, 2014).

\section{FIELD RESEARCH METHODOLOGY}

Considering the aims of the study the explorative approach is seen as the most appropriate. Moreover, there is an important limitation - number of companies practiced AMS is pretty limited. So that it is decided to employ case study approach for a broad investigations of AMS introduction in European enterprises. As Denzin and Lincoln (2009) underline, the case study methodology is being used in many fields of social research as well as other sciences. Creswell (2007) states that case study is a good approach when the inquirer seeks to provide in-depth understanding of the cases or a comparison of a several cases. As this is a qualitative methodology the doubtfulness refereeing to the reliability in study validity is quite substantial. Therefore the researcher should use multiple sources of evidence to demonstrate coverage of data from all sources, moreover a chain of evidence that link parts together should be established (Burns, 2000, p. 476).

Considering whole the limitations in the business entities as well as the nature of case study methodology, the multiple case study is decided as the most appropriate approach. Each case will be studied according to the same nodal points.

The investigation of each AMS will follow some substantial issues:

- basic characteristics of AMS organization in a company;

- tasks coordination and decisions; 
- manifestations of AMS philosophy;

- shortcomings form systemic point of view.

The objects of multiple case study methodology are three companies, one of them is located in Sweden and other two in Poland. First one is an automatized bottling plant of beverages producer. In this study it is called as "Company A". The second company is located in Poland. Its business activities are focused on cosmetics production. The company operates in two steps: mass batch production and halfautomatized packing. This company will be called as "Company B". The third company is an electrical equipment manufacturer with manual assembly processes. Its facilities are located in Poland. In this case study its name is "Company C".

All three companies operate worldwide. All of them have foreign ownerships - they are parts of larger holding companies operating internationally. Each of companies chosen for investigation has experiences with AMS, and what is crucial for this study, their experiences in this system are not equal. They operate in two different European countries with different historical economic background. Polish economy is a post-transition one with still strong and prescriptive management methods. Swedish economy is a high developed one. In terms of working culture and new technologies utilization, it is also very socially focused. Taking into consideration that AMS is not widely spread within European companies the objects selected for this multiple case study look as appropriate representation for studying European experiences referring to implementation of amoebas approach in companies.

\section{AMOEBA'S SYSTEM IN THREE STUDIED COMPANIES}

Each of the three amoeba's systems are analyzed according to the same criteria. The information is obtained from personal visits in production facilities, careful observations and unstructured interviews with managers. During data collection and analysis, the researchers focused on the differences and similarities of the crucial characteristics of AMSs existing in research objects. Particular observations were systematically confronted with the available literature on AMS. Shortcomings and challenges faced in the investigated AMSs in their development paths formed the focal point of the filed investigations.

\subsection{The Starting point OF AMS}

First of all, the different imperatives to introduce amoeba approach are observed in three researched companies. Company A initiate the kaizen teams approach in the year 2000. They set the goal to improve efficiency of production lines as well as productivity of a workforce. After 1 year management noticed that workers want to take responsibility for their lines' results. First roles as quality responsible operator, technics responsible operator appeared in teams. In 2003 managers noticed a greater responsibility by operators for the processes they working on, so that they decided to establish a team member with a role of a coordinating operator. This was a special moment for this company. A turning point for the company's organizational system. „In this year we broke through stereotypes and the old corporate culture; but we also saw a need to enrich the operators knowledge and skills as well as to change our management habituations and some behaviors of our operators" (CI Director, Company A). The company started to be „employees focused" as an element of its mission. The beginning of AMS in Company A, generally, was line workers driven.

In 2009 Company B appointed to a General Manager position a person described as „an outstanding leader $(\ldots)$ his sense for strategic topics and open mindedness makes him an excellent manager with a vision beyond pure target achievement" (Manager, Company B). GM worked out with his management team values of led company: "trust, courage and care", which become a foundation of changes in this company. First steps where made in management attitude and leadership behavior fostering. Kaizen actions and kaizen teams were appointed to follow growing targets and to create environment of continuous improvement. „But it was not enough for us, only some of operators had possibility to take part in changes. Rest of them had a role of observers" (Production Manager, Company B). In 2014 the company decided to implement autonomous teams to simplify organization, communication and give all employers real influence on their work environment. The communication of autonomous teams was started with words „our mission is to create value for us (work quality, safety) and for our customers (product quality and on time delivery)" (GM, Company B). The beginning of AMS in Company B was generally driven by management particularly by one strong leader - a General Manager. 
The starting point looks differently in Company C, which followed directions derived from their head office. In 2014 head office informed that autonomous teams was the management approach that must be implemented in the strategic perspective of next 4 years. Internal analysis had shown that current Production Manager attitude and behavior would not allow to introduce the expected organizational system. At the end of 2014 a new Production Manager was appointed with the mission of autonomous teams creation. His first steps were concentrated on autonomous teams leaders formation and change of the behavior of supportive departments. „Without leaders understanding of their role for us (management) and for their teams, without development of their leadership skills, without changing behavior of other departments to support team leaders, we can't expect the organization and autonomous teams will support our company growth" (Production Manager, Company C).

\subsection{AMS CHARACTERISTICS in Company A (SWEden)}

In Company $\mathrm{A}$ the system of amoebas exists in three levels structure, that is: level of top management, department managers and autonomous teams. In each team three typical roles are distinguished in a bottom up manner, these are: a team coordinator, quality responsible and a technician. The qualification to these roles is based on the employees skills and talents. A team size is up to 15 operators, but it differs depending on individual work area needs. In this AMS, managers support autonomous teams. Teams provide systematic performance analysis on a daily basis, exactly like this in Inamori's system at Kyocera. The team results are measured by daily operational indicators, but they do not have a financial nature. The operator salaries do not depend on a team performance but are based on work competences.

In AMS particular attention is devoted to the operators' preparation to their work responsibilities. At the beginning, a team coordinator is provided a cycle of leadership trainings as well as mentorship from an experienced leader or manager. After the preparatory stage, a team coordinator participates in cross functional meetings and workshops which are intended to support him/her in daily decisions and provide with the area expertise knowledge. An ordinary team member, at the beginning, also receives a cycle of trainings closely linked to his/her future role in a team. This learning process last approx. 3 months. During the work an operator participates in problem solving workshops in area of responsibility (quality or maintenance). Operators are actively engaged in determination of standards and instructions in relevant working areas.

Targets come from company strategy and are cascaded down to all company departments and levels, finally reaching autonomous teams. During the time the system was observed, set operational targets were exceeded up to $10 \%$ showing that teams are more concentrated on continuous improvement and looking for unnecessary losses then just a set target. Company A managers report some results achieved thank to the AMS implementation. They are as follow:

- team reduced their workload, this extra time is utilised to make next improvements in team area, during this time also other team areas are supported in improvement actions;

- there were observed noticeable reduction of employees rotation;

- the yearly targets have exceeded by teams each year;

- and finally there are noticeable higher maturity of team members, they manifest a real responsibility for area's performance and are partners in targets setting.

On the other hand as the most important shortcoming to AMS described by Inamori (2014) is not implemented financial indicators for autonomous team.

\subsection{AMS CHARACTERISTICS in Company B (Poland)}

In Company B the system of amoebas exists in three levels structure, there are: level of top management, department managers and autonomous teams (amoebas). There is no distinguished roles between workers in teams. A team size is up to 50 operators and it differs depending on individual work area needs. The influence on team size have also temporary workers who creates even $25 \%$ of production staff in peaks periods. In AMS of Company B, managers support autonomous teams by teams' systematic performance analysis on a daily basis. The team results are measured by daily operational indicators and they do not have a financial nature. As there is no roles in teams, role of manager is important. He is still a leader who support 
systematic performance analysis of subordinated teams, he creates next targets and appoints kaizen teams to solve appearing problems in reaching targets. This creates strong role of kaizen teams focused on set goals in areas set by managers. The activities of kaizen teams (not autonomous teams) brings exceeded targets up to $5 \%$ each year. The operator salaries are based on working hours with bonus on long term goals achievement. The role of bonus is to support sustainability of improvements prepared by kaizen teams.

Company managers highlight the problem of autonomous teams management. „We eliminated level of team leader what simplified communication but in the same time we (managers) must manage up to 120 people in one time" (Production Area Manager, Company B). At the same time change in managers participation on genba was noticed: "finally they are present on shop floor and understand real needs of their people" (GM, Company B). And yet all managers, basing on current experience, see the crucial need to prepare team members to manage themselves and their results.

The problem which Company B is facing with is also attitude of working in kaizen teams instead of autonomous teams. Kaizen teams are built with „who wants" members. These members are taught to concentrate on targets achievement in set (not always their) area. In fact, the kaizen teams, not members of autonomous teams, are responsible to achieve results, what is considered as a real threat. On the other hand, in each autonomous team there are kaizen teams members who already have skills to work with challenges and targets. The weakness is that all the kaizen targets are set by managers not autonomous teams.

Next challenge for Company B is how to integrate temporary workers into autonomous teams. The temporary workers employment is the mean to follow changes in customer demand and to reduce risk of unnecessary stock levels.

The example of Company $\mathrm{B}$ showing that implementation of AMS is not only "to cut" one level of organizational structure. Operational teams are not learnt to be self-governing. Interviews with operators show that they still expect leadership and guidance. The question discussed in management team is which way to choose now: appoint a leader in (not over) a team and develop operators skills to support the leader or teach the team how to work autonomously? Management is convinced to second option thought assess it as more difficult solution. Training paths are in preparation phase.

\subsection{AMS CHARACTERISTICS in Company C (Poland)}

In Company $\mathrm{C}$ the system of amoebas exists in four levels structure, there are: level of top management, department managers and autonomous teams leaders and autonomous teams (amoebas). There is no distinguished roles between workers in teams. All team members are operators in assembly cells. At this phase of AMS concept implementation Company $\mathrm{C}$ is putting high attention to team leader role whose current responsibility is to create autonomy of his area. This goal is reached by slowly retreating leadership of a production manager and change in the role of supportive departments. Each daily performance visual management meeting is led by a team leader who highlight results, gaps and needs of his area. Supportive departments as: planning, maintenance, quality and warehouse, come to this meeting to give the answer on leaders questions, support his/her decisions and agree common action plan. The goal is to support leader in his/her team performance achievement and to find compromise in conflict situations. This daily meeting is also a place where a leader, basing on long term production plan, defines the need of extra workers in his area and need of technical development of area. The only role of a production manager is to react when the team is not able to find compromise.

Each team leader manages a team up to 30 operators. The size of the team differs depending on cells' needs. One team leader is responsible for few cells (sub-teams) to ensure flexibility in moving workers between cells when it is needed. In the same time managing of 30 people is seen by team leaders as difficult and not allowing a real participation in team life as well as in-depth understanding the problems roots.

Team members salary system is based on working hours with discretionary bonus awarded by a leader. Team leaders passed through leadership, communication and negotiation trainings with strong pressure on performance and firmly basing on a visual management tool - Performance Visual Management (PVM). Participation of production manager in PVM meetings allows him to ensure coaching and mentoring of each leader as a reaction on his/her successes and failures. 
Concentration on autonomous team leaders left team members behind the autonomy. The only influence that they have on their work environment is to suggest solutions by participation in suggestion programme. All their suggestions are analysed on daily basis and are part of PVM meeting. This solution is a part of operators teaching plan - by getting feedback operators learn which suggestions are valuable for company. The results can be seen. Fast reaction on highlighted problems and implementation of big part of suggestions motivate operators to propose next improvements. But there is still a gap in communication between leaders and their teams. Operators do not participate in formulation of improvement action plan and are not guided to follow targets different than productivity. All other targets as e.g. production plan fulfilment are the team leader responsibility. This gap is seen by management especially in targets achievement (all teams leaders just try to follow targets) and Company $\mathrm{C}$ is preparing plan to implement PVM meetings to leader-team level.

The activities of kaizen teams in Company $\mathrm{C}$ is almost invisible on shop floor, exactly the same way as it was 3-4 years ago. All improvements are shared between departments and cells or teams and implemented internally step by step. There is still management conviction that the main role of operator is to make products and not "lose time on improvements". The improvement role is moved to departments to understand suggestion and the need highlighted by operator and implement it. Company $\mathrm{C}$ is planning to observe if this solution will be sustained or not, basing on leader-team PVM meetings results.

\section{DISCUSSION OF THE RESULTS}

The observations made in companies should be confronted each other and with the literature knowledge. All three investigated companies decided to eliminate finance analysis from their AMS. „There is no such a will to share with employer detailed information about cost and profits of our organization" (Production Manager, Company C). „There is a risk to inform them (workers) about difficulties of our business as we want them to feel safe in our organization. From the other side, there is a risk that employers knowing our profits can expect higher salary. And this is the area on which we have really weak influence as managers of foreign companies" (GM, Company B). „When is a need to control costs we discuss and control it on teams level" (CI manager, Company A). Teams are driven by Key Performance Indicators (KPI) which are connected with financial indicators. Thanks to this solution companies eliminated part of conflicts in price negotiation between amoebas. And what is important, by this way they eliminated the risk of instability feeling which job rotation can generate. In the same time they are developing teams responsibility and autonomy. This decision has consequences in indicators definition to put attention of team members on costs. Each company chose different way to solve this problem: some of them defined indicators which has direct influence on costs as for example scrap level measured in measure units (Company B\&C), and others showed real costs e.g. scraps in value unit (Company A).

The problem coming from not using financial indicators on operational level can be seen in support areas/departments such as: sales, planning, purchasing, sourcing. Only Company A with welldeveloped company culture and with a mission of "common goal" is not facing with a problem of conflict of "which department is more important” and „whose goals are more important”. Company C reduced the problem by redefining roles of supportive departments putting into centre production area which goal is to fulfil customers' orders on time and with zero complaints. Company B manages inter departments balance on the level of departments managers.

The challenge of finding common language between managers and operational staff companies solved in different ways:

- Company A - company culture and country working culture is based on real respect between workers and managers; sporadic conflicts are solved by labour unions supporting both: employee and employer;

- Company B - runs programmes of "Culture of agreement" and "Team voice" to reduce the distance between managers and operational staff and leadership development programs for managers;

- Company C - implements effective PVM solution supported by very simple Workers Idea Programme.

Another very interesting issue is the role of salary system in achieving amoeba targets. Company A and 
$\mathrm{B}$ show that there is no need to motivate employers by bonus for meeting monthly targets to exceed targets. Company $\mathrm{C}$ results confirm that meeting targets is the result of daily targets management by PVM and not by bonus for top operators or even all of them.

Interesting observation is that all 3 companies created autonomous teams only in production area. "This is the field which needs this solution, other departments already work autonomously" (Production Manager, Company B). „The production needs autonomous teams to show they are authorised to define their needs" (Production Manager, Company C).

In all companies there is seen progress in comparison to typical companies not using amoeba concept from their industries located in the same geographic area as well as comparing to the state before AMS has been introduced. The progress is seen in how workers asses management of production processes. "Finally they react faster for our improvement suggestions. Sometimes it takes too long time, but reasons of delay are impartial" (Operator, Company B). "There is a big change in managers attitude. I never believed that maintenance manager will ask me how he can help me" (Team Leader, Company C).

Some significant shortcomings were also observed as regards to people attitudes and self-confidence. Interview made with leaders of Company $\mathrm{C}$ shows the fear of taking the responsibility. „We are scared. Autonomy means high responsibility. I am not sure I have enough skills to fulfil all expectations. I don't want to lose my job ..." (Team Leader, Company C).
Workers understand the need of taking this responsibility, but they feel the lack of real support from managers. „Our managers don't fully know what problems we are facing with. They are too far from our lines. Having authority to change we can make improvement faster" (Operator, Tab. 2. Studied AMSs maturity assessment

\begin{tabular}{|c|c|}
\hline STUDIED COMPANIES & MATURITY LEVEL \\
\hline Company A & advanced \\
\hline Company B & medium \\
\hline Company C & beginning \\
\hline
\end{tabular}

Source: authors' elaboration. implementation is proposed as following:

- full: a production manager plays a supportive role in AMS, no team leader level in organizational structure; team members has defined roles in teams; daily communication throughout whole organizational levels, meaningful results referred to targets; implemented financial indicators for each amoeba, flat organization structure ready to be changed any time;

- advanced: in this level are the same like in the „full” level, namely active role of a production manager, appropriate managerial levels and defined roles in an amoeba team, but financial indicators, including transfer prices, do not play as fundamental factors steering amoeba teams;

- medium: a production manager role in amoeba management is still important, no team leader level in organizational structure; team members has no defined roles in teams; daily communication not through all levels of organization, targets achievement according expectations, flat organization structure;

- beginning: important production manager role in amoeba management, organizational structure has more than 3 levels; team members has no defined roles in teams; daily communication between single level of organization, weak results in targets achievement.

The investigates AMSs in the three companies are qualified to maturity levels basing on the systematization proposed above. The AMSs maturity are presented in Tab. 2.
AMS there is important remark coming from team members: „We will observe our managers, if these long term plans, to change their attitude and way of treating us, will be fulfilled..." (Operator, Company B).

Basing on AMS literature review and the investigations and observations in companies, also having in mind highly entrepreneurial and engaged idea laid as basis of AMS approach, a scale for assessment the maturity of autonomous teams

\section{CONCLUSIONS}

The multiple case studies argued that the real big challenge for companies which would like to follow amoeba approach is to introduce appropriate financial approach including an adequate accounting system, financial planning and targets in the amoebas level as well as transfer prices between amoebas. The literature 
insight into the AMS at Kyocera shows that financial planning and financial responsibility of amoebas is an essence of this approach (Inamori, 2013; Sawabe et al., 2008; Hamada \& Monden, 1989). Only this enables fully entrepreneurial behaviours of autonomous teams, it lets far-reaching rationalization of business operations in all their dimensions. The study also suggests that the transition to a financial settlements of amoebas is a fundamental shift in a company, this shift is an ultimate one. The two other really important challenges, for those who want to implement AMS to existing companies, are to set a new leadership approach by top managers and change attitudes of operators and leaders. Both challenges need to be supported by wide competencies development.

The transformation from the traditional management system to AMS proposed by Inamori (2014) cannot be done as a revolutionary short term action. Changing convictions, behaviours and beliefs is the long term evolutionary process which can be divided in four steps.

First of all, there is a need to concentrate attention of each organization level to KPIs and teach them methods to reach set targets. This task can be supported by Goals Pyramid (GP) and PVM tools. Whilst creating GP there is an important role of managers to understand the processes led through departments. Creation of departments KPIs must be based on processes and balance interests of each department to reach key company financial targets. The biggest challenge of this tool is to eliminate conflicts of interests between departments. PVM role is to support managers/leaders in creating attention and initiate activities of his team to reach set indicators targets. In this step, the manager is the leader and guide for his team. He makes decisions which are followed by a team.

Second step is to authorize leaders and operators to make autonomous decisions being guided by KPIs. The authorisation of subordinating staff needs a belief that their decisions will be according to managers expectations and entirely approved by them. That is why this step needs competencies development to give the know-how to staff. Competencies development can be reached jointly by trainings, muda walks and participation in kaizen actions concentrated on reaching targets. In the same time team decisions can be controlled by reversed PVM where the manager/leader is a customer of team results. In revised PVM the role of manager/leader is to give the feedback to decisions and ideas made by the team to teach them expected decision making processes.

Third step is to join interests of different departments and concentrate them on common goals. This step is already supported by KPIs pyramid developed in step 1 but at this stage should be concentrated on natural cooperation between representatives of different departments. This cooperation should be led on operational level and engage operators and specialist. The goal of this step is to work out cooperation rules on operational level of organization which support cooperation based on departments managers. Third step needs widening of competencies on understanding processes led through departments.

The fourth step is to convert the KPIs to financial indicators. This step needs financial competencies development through all organizational structure. Here, the financial system proposed by Inamori (2014) can be implemented.

Proposed by authors, four steps development process is concentrated on set of tools which, step by step, build trust in organization, conviction that operators can be authorized to make autonomous decisions (Inamori, 2014; Smythe, 2009) and create culture of agreement (Levine, 2006; Smythe, 2009) between all levels of organization and across departments.

\section{LITERATURE}

Adler, R. W., \& Hiromoto, T. (2012). Amoeba Management: Lessons From Japan's Kyocera. MIT Sloan Management Review, 54(1), 83-89.

Aon Hewitt (2015). Report of Trends in Global Employee Engagement. Retrieved from: http://www.aon.com/ attachments/human-capital-consulting/2015Trends-in-Global-Employee-Engagement-Report. pdf

Bart van Ark (2015). Report: Global Economic Outlook 2016 - Key Findings. The Conference Board Inc. Retrieved from: https://www.conference-board.org/data/globaloutlook/

Blahová, M. (2013). Effective Strategic Action: Creating Dynamic Performance Framework Based on the Utilization of Synergy Effects of Bata, Japanese and Amoeba Management Systems, doctoral thesis. Zlin, Czech Republic: Tomas Bata University in Zlin, Faculty of Management.

Burns, P. (2005). Corporate enterpreneurship. Building an entrerpreneurial organization. New York, USA: Palgrave. 
Burns, R. B. (2000). Introduction to Research Methods. London, Great Britain: Sage Publications.

Castellina, N. (2015a). Business Process Optimization and Change Solutions: Innovative Technology for Agile Bussinesses. Aberdeen Research, January. Retrieved from: http://www.aberdeen.com

Castellina, N. (2015b). Innovate with Business Driven Workflow Automation. Aberdeen Research, December. Retrieved from: http://www.aberdeen. com

Creswell, J. W. (2007). Qualitative Inquiry \& Research Design. Thousand Oaks, USA: Sage Publications.

Denzin, N. K., \& Lincoln, Y. S. (2009). Metody badań jakościowych [Qualitative research methods]. Warsaw, Poland: Wydawnictwo Naukowe PWN.

Hamada, K., \& Monden, Y. (1989). Profit management at Kyocera Corporation: the amoeba system. In Y. Monden, \& M. Sakurai (Eds.), Japanese Management Accounting - A World Class Approach to Profit Management (pp. 197-210). Cambridge, USA: Productivity Press.

Hay Group (2015). Nowe zasady angażowania pracowników [The new rules of employees engagement]. Retrieved from: http://www.haygroup.com/downloads/pl/ raport_nowe_zasady_zaangazowa-nia_pracownikow.pdf

Inamori, K. (2014). Zarządzanie Ameba. Każdy pracownik $w$ roli głównej [Amoeba Management. Every employee in the main role]. Poznań, Poland: Exemplum.

Inamori, K. (2013). Amoeba Management. The Dynamic Management System for Rapid Market Response. Boca Raton, USA: CRC Press.

Kazuo Inamori Official Website. http://global.kyocera.com/ inamori

Kyocera Consulting Group. https://www.kcmc.co.jp/en/ about_us/dounyuu.html

Levine, S. (2006). High performance organizations: creating a culture of agreement. Handbook of Business Strategy, 7(1), 375-380.

Moon, M. M. (2015). The new 70:20:20: The changing face of learning. Aberdeen research. Retrieved from: http://www.aberdeen.com

Sawabe, N., Kazusa, Y., \& Ushio, S. (2008). Dialectic Dynamics of Management Accounting and Management Philosophy. NZMA.

Sawabe, N., \& Ushio, S. (2009). Studying The Dialectics between and within Management Credo and Management Accounting. The Kyoto Economic Review, 78(2), 127-156.

Sawabe, S. (2015). Value-driven responsibility accounting: dynamic tensions generated by competing values embedded in the management control system. Discussion Paper No. E-14-020. Kyoto, Japan: Kyoto University, Graduate School of Economics.

Smythe, J. (2009). CEO - dyrektor do spraw zaangażowania [CEO - Director of commitment]. Kraków, Poland: Oficyna Walter Kluwer Business.

Takeda, H., \& Boyns, T. (2014). Management, accounting and philosophy. Accounting, Auditing \& Accountability Journal, 27(2), 317-356. 